\title{
Den litterære kentaur
}

I de sidste årtier har den ene kortlivede modebølge efter den anden skyllet hen over universiteternes litterære fag. Det har bragt nogle erfarne bekymrede forskere til at stille det spørgsmål til en række kolleger, hvoriblandt mig selv: Er dette noget, der skal vare ved? Skal vi hvert andet år læse os ind i nye teorier, der gør det af med dem, vi lige har lært? Eller findes der faste videnskabelige holdepunkter, som består, mens moderne forgår?

Et grundigt svar på spørgsmålene ville være en omfattende sag, næppe gennemførligt for nogen nu og heller ikke, hvad der anmodes om. Hvad der skal gives i det følgende skitseagtige indlæg er da også kun en række markeringer til afgrænsning af litteraturens og litteraturforskningens sted. Hvert led behøver yderligere uddybning.

De, der stiller spørgsmålene, er urolige for 'litteraturvidenskabens' fremtid. Måske ligger hele misèren i det ord videnskab, så man i stedet skulle spørge: Kan al den intelligente aktivitet, der udfolder sig omkring litteraturen, overhovedet kaldes videnskab i dette ords nutidige betydning?

Det er nok det, den ikke kan, men gerne vil, for ordet giver prestige og legitimation og har gjort det i mere end hundrede år. Da Georg Brandes endnu var ung og ubeskadiget, udtalte han i Den romantiske Skole $i$ Tyskland (forelæst efteråret 1871, trykt 1873): "Som den, der vil botanisere, må gribe om brændenælder såvel som om roser, således må den, der vil studere litteraturen, vænne sig til med naturforskerens og lægens uforfærdede øje at se alle former af menneskevæsnet $\mathrm{i}$ deres forskellighed og indre sammenhæng. "Her strenger han sig an for at ligne en naturvidenskabsmand, en, der ikke deltager i det liv, han observerer, men allerede halvåret efter, at han havde talt sådan, oplevede han i nogle saligt euforiske sommerdage og nætter, for han kunne ikke sove af begejstring, at det ikke mere var nødvendigt at styrke sig ved sammenligning, for ordet, det ene, der sidestiller naturvidenskab og åndsliv, var nu fundet: association.

Han skrev til sin ven og fætter Carl Salomonsen, at han wville

Aage Henriksen er professor i nordisk litteratur ved Københavns Universitet. 
grunde vor filosofi her i Norden på en ny basis, en sand basis, der tillader påvisning af aldeles bestemte, uomtvistelige love, ganske som $\mathrm{i}$ mekanik og kemi. Du kan også godt lade dig forlyde med, at al den anden filosofi her i Danmark er hjernespind og snak, idealistiske drømmerier, og lad dem sætte mig et sådant eftermæle, at denne person definerede filosofien som videnskaben om andens love og fordristede sig til at mene, at den således stod i rang med naturvidenskaberne, der er videnskaben om naturens love. Al filosofi er psykologi. $\mathrm{Al}$ psykologi hviler på iagttagelse. Al psykologi er læren om associationerne, associationer af sanseindtryk, af billeder af ideer og navne. ....Troen på jegets eksistens er kun association af erindringer. Jegets dannelse sker ved association $\mathrm{i}$ kraft at glemselens og erindringens love. Moralen er kun association af visse formål med begrebet det højeste gode.«

Det hele projekt blev kun en episode, som ikke efterlod sig spor, og den ville ikke være værd at omtale, hvis ikke den var så festligt naiv, og hvis ikke princippet, at læse subjektet ud af nogle simple objektive formler, der op til de sidste år har avlet nye, stadig ikke levedygtige konstruktioner, her kunne ses i sin nøgenhed. Men her sad den højtbegavede og omstridte, mærkeligt sammensatte og ganske ukemiske dr. Brandes og så sig selv løbe sammen af tilfældige indtryk, som associationen så igen klistrede sammen til en personlighed. Og omkring ham lå det væv af omstændigheder, som havde gjort ham til den, han var, men han kunne ikke få øje på det eller ikke overskue det, og han havde heller ikke midler til at løse det op.

Drømmen, som bærer dette og mange senere udkast til en objektiv humanistisk teori og metodelære, er forestillingen om, at også den forsker, som beskæftiger sig med historie og kunst, kan objektivere sig selv; så han - ligesom fysikeren tilsyneladende - kan stå udenfor den virkelighed, han vil erkende og gribe ind i. Der synes hver gang at være tale om det samme, at en emancipatorisk stræben, der forholder sig kritisk til den kulturelle tradition, overfører sin egen isolation og sine kontroversielle interesser til den teoretiske position udenfor den samfundsmæssige dialog.

At dette sted ikke findes, i det mindste når det gælder traditionsforskning, og at emancipationen først finder sit holdbare virkefelt, når de historisk-kulturelle fag adskilles fra naturvidenskaberne som en kundskabssfære for sig, det udvikles med overbevisende tydelighed i Jürgen Habermas' tætte, lærde og vanskelige bog Erkenntnis und Interesse (1968).

I denne bog giver Habermas en indgående redegørelse for det sidste århundredes faglige selvrefleksion, som C.S.Peirce har foreta- 


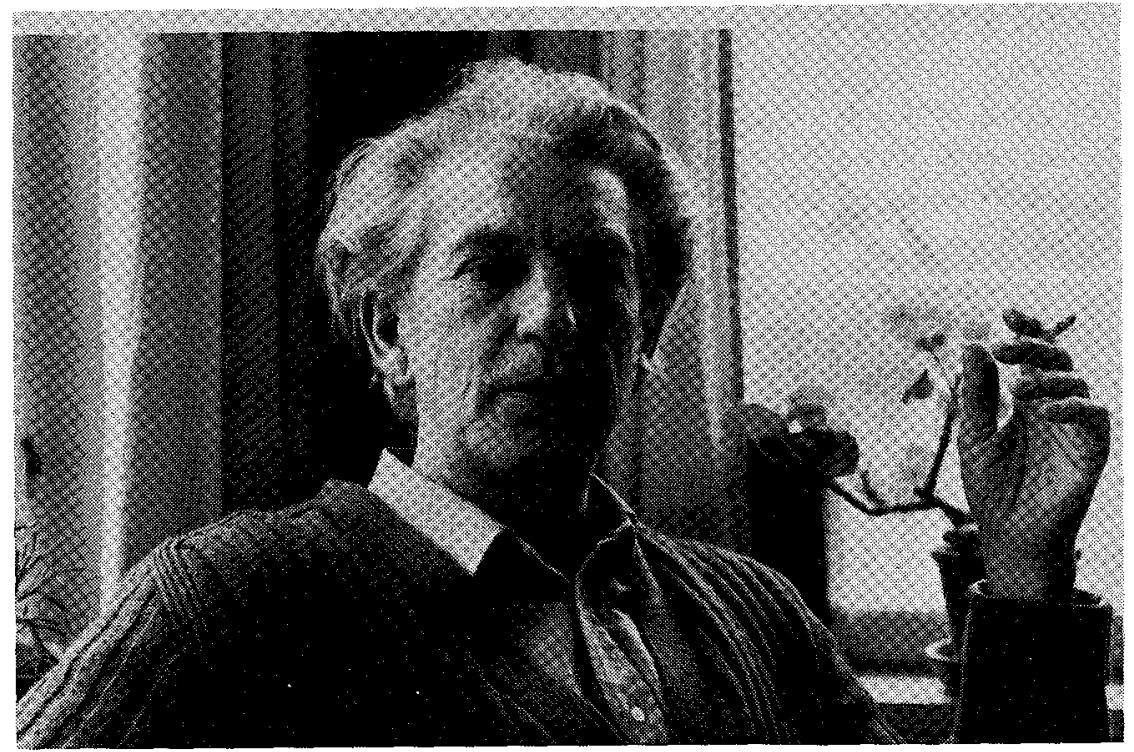

get for naturvidenskabernes og Wilhelm Dilthey for åndsvidenskabernes vedkommende. I naturvidenskaberne, der sammenfattes under betegnelsen 'funktionskredsen for instrumental handlen', er det muligt helt at abstrahere fra alle livshistoriske forhold. Alle livserfaringens momenter undertrykkes til fordel for almene, til enhver tid gentagelige effekter, hvis indbyrdes forhold kan udtrykkes i et formaliseret teorisprog, hvori navne på individer ikke kan forekomme. - I åbenlys modsætning til dette vidensområde står åndsvidenskaberne, der har en overlevet kontekst af betydninger som deres emne. Målet er her at forstå, men det, der skal forstås, er indfældet i livssfæren, udformet $\mathrm{i}$ dagligsproget, og er alene tilgængeligt $\mathrm{i}$ det dialogiske forhold, som betegnes intersubjektivitet. Forståelsens kunst, hermeneutikken, vokser frem af praktiske livserfaringer, 'livets tankeskabende arbejde', og omslutter uopløseligt det, der skal forstås, og den, der søger forståelsen.

De to kundskabsområder falder da for Habermas fra hinanden $i$ to selvstændige kredse: $\mathrm{i}$ den instrumentale handlen og den kommunikative handlen. De undgår dog selvfølgelig ikke gensidig påvirkning. Den grundlæggende tanke i bogen er, at den instrumentale handlen i sin trinvise udvidelse formindsker den tvang, som den ydre natur udøver over mennesket. I takt med indskrænkningen af den ydre tvang, som har nødvendiggjort en restriktiv moral, der havde det formål at kanalisere al menneskelig energi ind i den fælles overlevel- 
seskamp, kan også undertrykkelsen af menneskets indre natur gradvis hæves. Men skønt begrundelsen for den falder bort, overlever den dog som vedtægt. Og denne vedtægt, men det er nu kort fortalt, fremtræder i det ydre som det fortsat eksisterende klassesamfund og $\mathrm{i}$ individets indre som neuroser. $\mathrm{Ud}$ af dette forhold/misforhold rejser sig så bogens pointe, at der med Freuds psykoanalyse er opstået en lære i metodisk selvrefleksion, som afdækker undertrykkelsens mekanismer og følger. Læren er ganske vist af Freud selv fejlagtigt blevet henført til naturvidenskaberne, skønt dens rette sted er området for kommunikativt handlen. Men uanset dette, så udvider denne selvrefleksion hermeneutikken langt ud over dens kendte grænser, og med dens midler bliver det muligt at ophæve det brud i menneskets indre, som den samfundsmæssige repression har fremkaldt, så mennesket igen forenes med sin sande natur.

På denne måde bliver psykoanalysen vejviseren, der peger ud over positivismen. "At fornægte refleksion, det er positivisme." Og i sin uafsluttende form bliver dog psykoanalysen forløberen for Habermas' utopia, det magtfri kommunikative fællesskab.

Som en moderne mestertænker, der kan bane sig vej igennem ellers ufremkommelige filosofier og videnskabsteorier og bevare overblikket, når han kommer ud igen, er Habermas en sjælden mand $i$ tiden. Hans grundlæggende skelnen mellem vidensområder synes uimodsigelig. Hans forestilling om, at selvrefleksion er vejen til nye kundskaber, støttes af mange troværdige signaler. Men hans tankes fundament er teorier, og hans individer, når de forekommer, genstand for teorier. Litterære værker og skæbner indgår ikke $\mathrm{i}$ hans argumentation. Hvis de gjorde, ville de kunne bringe ham i vanskeligheder. Man kan tydeliggøre det ved nærmere omtale af en iøvrigt meget nyttig konstruktion, begrebet 'den litterære institution',som ganske vist skyldes Escarpit, men passer præcist ind i Habermas' egen materialistiske åndshistorie, Strukturwandel der Öffentlichkeit (1962, (norsk Borgerlig Offenlighet).

Udtrykket 'den litterære institution' sigter som bekendt til den ændring $\mathrm{i}$ litteraturens status, der indtraf på forskellige tidspunkter $\mathrm{i}$ Europa, i Danmark i sidste halvdel af det 18. århunderede. Mens litterære værker indtil da hovedsagelig havde stået i tjenende forhold til de store samfundsinstitutioner, fyrsterne, kirken, centraladministrationen og illumineret deres opfattelse af det sande og gode, så frigjorde digterne sig med det borgerlige samfunds tilblivelse fra tjenesteforholdet, og der opstod samtidig en omfattende væuning af litterære selskaber, forlag, kritiske publikationer m.m., som tog sig af litteraturens fortsatte liv. Det er denne konstellation af selvstændige, 
men forbundne initiativer, der er blevet kaldt den litterære institution.

Udtrykket tilhører den sociologiske litteraturforskning, men viser sin funktionsdygtighed ved at kaste lys også over andre, mere tilslørede sider af litteraturens liv. Ved den litterære institutions tilblivelse blev digterne henvist til at producere med deres personlige erfaring som materiale. At udfolde fantasi over erindringens spor. Det er en ny, mærkværdig situation, som nu har varet så længe, at den er blevet en selvfølge. Den fører i bred emnemæssig henseende med sig, at nye temaer sætter sig igennem, livet pålangs, udviklingsforløb, psykologi - individet overhovedet. Og disse emner trækker et andet, meget udbredt med sig, et mere indadvendt, som spejler situationens mærkværdighed, værker om værkers tilblivelse, produktiviteten som sin egen genstand.

Tilsammen bringer denne kreds af emner en ny dimension af menneskets væsen frem til synlighed, bevidsthedens univers. Det har i løbet af de to århundreder, det har været kendt, fået sin idealistiske og sin materialistiske udlægning, der begge må anses for foreløbige; det befinder sig stadig på vejen op i lyset. Snarere er det sådan, at med dette store og omvæltende emne begyndte en ny tidsalder, der stadig søger sin balance.

Kunstnerproblemet, som blev nævnt, kan bruges til at åbne perspektivet. Hvis den sag løses ud af de følsomme biografier og betragtes psykologisk eller filosofisk, så afdækker den så godt som ubenævnte træk ved virkeligheden. Det drejer sig i al korthed om, at bestemte skriveprocesser, fx. i bundne rytmer, over nøjagtigt fastholdte erindringsforløb eller lignende, kan frigøre en tilstrømning af indsigt og sprog, som forfatteren ikke ellers, ikke selv rådede over. Det er den første, overraskende og uimodståelige oplevelse, som altid henrykker. Op igennem tiden har digterne kaldt den identitet, som slutter sig til deres egen, med så forskellige mytiske navne som Føbos, Prometheus, Odin og Lucifer. Det andet, senere, er opdagelsen af, at værket, som frembringes i denne tilstand, ændrer den, som frembringer det, ved at gøre de kendte glæder og tilfredsstillelser, som socialt liv beror på, mindre attråværdige og tilsidst helt værdiløse. Det tredie trin i denne proces er bruddet med den indøvede måde at producere på. Man kan følge det $\mathrm{i}$ berømte forfatterskaber som Grundtvigs, Johs. V. Jensens, Martin Andersen Nexøs og Martin A. Hansens. På et givet tidspunkt i deres liv føler de sig truet af deres egen produktionsmåde, forkaster den og vælger sig ind under en offentligt anerkendt, socialt etableret ideologi, som kan være den kirkelige tradition, evolutionslæren, den internationale arbejderbevægelse eller retsynet i nordisk middelalder. 
Andre derimod som Henrik Ibsen og Sophus Claussen forbliver livet igennem i de første anlagte spor.

Der rører sig stærke kræfter i dette mærkelige spil. Her skal det blot fastslås, at en så lang række af vores betydeligste forfattere har været impliceret i disse erfaringer, at de kan hævdes at være konstanter $\mathrm{i}$ nyere litterær historie. Når forfattere tror, at de er alene og udefra beskuer menneskelivet, så erfarer de, at de er omspændt af stærke bevidsthedsenergier, som de har givet adgang. At deres virksomhed, ganske udenfor hensigten, er en slags meditativ praksis, der ligger $i$ stærke personlige interessers forlængelseslinje.

På et tidspunkt i historien, omkring 1800, hvor disse erfaringer begyndte at gøre sig gældende, havde man også en officiel, unægtelig bekvem og ærefuld tolkning af dem. Idealismens centrale greb bestod jo i at krænge fortidens metafysiske univers omkring som en handske, så det, der før var himmel og helvede, blev inderverden, ubevidsthed, som i sin midte blev beboet af det absolutte jeg, alle levende væsners sidste identitet. Hvad der kom til talenter og genier som tilgift til deres egne tanker, var da udstrålinger fra dette højere jeg. Det var en lysere og venligere ubevidsthed, end den man senere har vænnet sig til, ganske sikkert da også for enkel og helt ude af stand til at forklare de nedture, der fulgte de lyse øjeblikke. Alligvel er denne tænkning værd at huske, fordi den i realistisk overensstemmelse med udbredte erfaringer udkastede billedet af et bevidsthedsunivers med opadstigende trin.

Idealismen var en officiel filosofi, der - i Danmark i en kirkeligt modificeret form - bar flere generationer, og som tilbød digterne en hæderfuld selvforståelse, forbundet med tingenes midte. Det karakteristiske for kunstnererfaringens senere historie er, at den, da litteraturen blev underlagt den almindelige fagspecialisering, mistede sin perspektivistiske betydning. Den er en erfaring af almen betydning og genkendelighed, som blot med særlig skarphed tegner sig i litterære livsforløb og der kan studeres. Men i de sidste hundrede år er erfaringen, spærret inde i de litterære fag, blevet et stykke kuriøs æstetik. Sådan som den fx. udfoldes i Hugo Friedrichs bog om Strukturen $i$ den moderne lyrik, hvor fabeludsagn af digtere som Rimbaud og Mallarmé opløses $i$ en subtil tale om afhumanisering, depersonalisering og tom transcendens.

Denne historie er ikke en sag om interessante liv og usædvanlige valg. Den stiller spørgsmålet, om de vedtagne forestillinger om bevidstheden overhovedet kan komme i forhold til de kunstnererfaringer, som i begge sine former, fortsættelsen og afbrydelsen af den første produktionsmåde, har været bestemmende for vigtige værdidannelser 
i de sidste århundreders kulturelle liv. Hvis de ikke kan, så er der stillet en opgave, som i sidste instans vil fremtvinge det så meget omtalte paradigmeskifte.

Opgaven ligger indenfor det dialogiske forhold, som er intersubjektiviteten. Den kan ikke udforskes med andre midler end selvrefleksionen, som igen ikke kan gennemføre sit analytiske arbejde uden en $\mathbf{i}$ forvejen antaget almen norm. For Freud var den lægelig, personlig trivsel, at hjælpe patienter, der havde det dårligt, til at få det bedre. Hos Habermas ses denne værdi, livskvalitet, indfældet i en større orden, det kommunikative fællesskab, som dog først kan komme i stand, når samfundet omdannes og den menneskelige driftsnatur får friere spil.

Udgår man derimod fra litteraturen som en kendsgerning, der gennembryder de bekendte bevidsthedsgrænser, og vil man i selvrefleksion følge denne bevægelse, så bliver det nødvendigt at bytte om på rækkefølgen i Habermas' tankegang og anlægge en ideal norm, som er bestemt af helhedens interesse. Den har jo i umindelige tider svævet i samfundet som offentlig moral. Med den som selvrefleksionens regulator vendes tingene om, og individet bliver nødt til selv at påtage sig ansvaret for sin tilpasning til den familiære og samfundsmassige repression. Men dermed vises der hen til en transcendent instans, en hidtil ukendt formende og vælgende identitet, som har skjult sig bag den sociale identitet. Den har i årenes løb ladet sig binde og kan ved selvrefleksionens biografiske dekonstruktion igen gøre sig fri.

Hvis man - en smule hypotetisk eller eventyrligt - tænkte sig denne selvrefleksion som litteraturforskerens metode, den fagbestemte emancipation, så ville han eller hun baglæns bevæge sig ind i det bevidsthedsrum, som driver digteren fremad. Så ville forsker og forfatter komme på erfaringshøjde med hinanden. Men samtidig ville en litterær kritik, der var modstandsdygtig over for nihilistiske modestrømninger, blive mulig. 